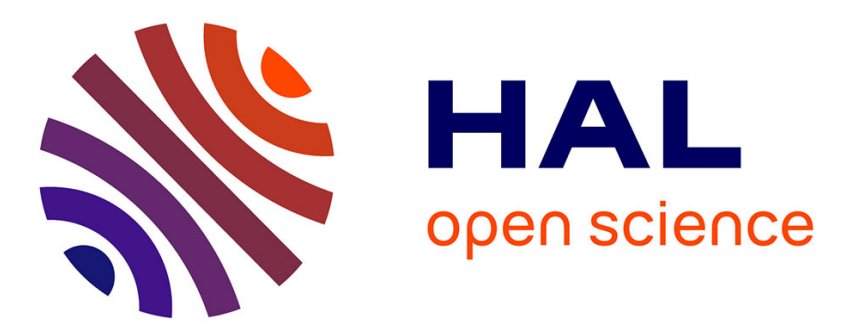

\title{
Growth, regeneration and colonisation of Egeria densa fragments: the effect of autumn temperature increases
}

Gabrielle Thiébaut, Morgane Gillard, Carole Deleu

\section{To cite this version:}

Gabrielle Thiébaut, Morgane Gillard, Carole Deleu. Growth, regeneration and colonisation of Egeria densa fragments: the effect of autumn temperature increases. Aquatic Ecology, 2016, 50 (2), pp.175185. 10.1007/s10452-016-9566-3 . hal-01269913

\section{HAL Id: hal-01269913 https://hal-univ-rennes1.archives-ouvertes.fr/hal-01269913}

Submitted on 2 May 2016

HAL is a multi-disciplinary open access archive for the deposit and dissemination of scientific research documents, whether they are published or not. The documents may come from teaching and research institutions in France or abroad, or from public or private research centers.
L'archive ouverte pluridisciplinaire HAL, est destinée au dépôt et à la diffusion de documents scientifiques de niveau recherche, publiés ou non, émanant des établissements d'enseignement et de recherche français ou étrangers, des laboratoires publics ou privés. 
2 temperature increases. F-35042 Rennes, France 2 : University of Rennes 1, UMR 1349 INRA-Agrocampus Ouest-Université Rennes 1,

7 Institut de Génétique, Environnement et Protection des Plantes (IGEPP), 263 avenue du 8 Général Leclerc, F-35042 Rennes, France 
Abstract:

12 The present study analysed the influence of higher temperatures on the growth, regeneration and colonisation abilities of apical shoot fragments from three naturalized and one cultivated population of Egeria densa. Our hypotheses were that (1) increased temperatures would favour the growth, regeneration and colonisation of E. densa shoots and (2) fragments from naturalized populations would have higher establishment success than fragments from cultivated plants. We tested the effect of average minimal autumn temperature $\left(9^{\circ} \mathrm{C}\right)$, average maximal autumn temperature $\left(16^{\circ} \mathrm{C}\right)$ and an increase of $3^{\circ} \mathrm{C}$ above these values, on apical shoots of these four populations of $E$. densa under controlled conditions in two growth chambers. Our results showed that temperature and the origin of the population had an effect on the growth rate of $E$. densa fragments, on their regeneration and colonisation abilities at the maximal autumn temperature. An increase of $3^{\circ} \mathrm{C}$ stimulated the growth rate of $E$. densa at low temperatures but had no effect on the plant colonisation and regeneration abilities. The responses of populations to low temperatures $\left(9-12^{\circ} \mathrm{C}\right)$ were more similar than expected. In contrast, at higher temperatures $\left(16-19^{\circ} \mathrm{C}\right)$ the cultivated population showed lower apical growth, higher regeneration and similar colonisation abilities to the naturalized populations. At these higher temperatures, the responses also differed among the naturalized populations. These results suggest that global warming has implications for the invasiveness of E. densa.

31 traits. 


\section{Introduction}

Climate change, variability and changes in land use are major drivers of ecosystem alterations. Non Indigenous Species (NIS) also contribute to ecosystem changes. They cause environmental damage, and have economic consequences and impacts on human-health. Interactions exist between these threats and they could exacerbate the impacts of climate change on ecosystems by changing environmental conditions, and climate change may also enable further invasions (Hellmann et al. 2008; Mainka and Howard 2010). Climate change could also affect the dynamics of plant invasions by favouring individual traits of invasive species (Hellmann et al. 2008). Aquatic non indigenous plants could benefit from the increasing seasonality and more marked wet and dry cycles.

In addition to physical changes, climate change can alter ecosystems and species' life cycles (Fitter et al. 1995; Bradley et al. 1999). Scientists have traditionally focused their attention on the seasonal changes in spring rather than those later in the year. Many studies have focused on spring events in temperate regions, while studies on the basic triggers of autumnal plant changes are, by comparison, in their infancy. Gallinat et al. (2015) consider that it is important to investigate the role of autumn climate change on NIS. The survival of invasive aquatic macrophytes in ecosystems depends, amongst other factors, on their thermal acclimation. Phenotypic plasticity and rapid evolution allow some invasive species to be more responsive to warmer autumn temperatures and to later freezing events than many native species (Richards et al. 2006), but there is a gap in our knowledge regarding invasive aquatic plant establishment and its responses to predicted climate change.

Among the invasive macrophyte species, Egeria densa Planch (Hydrocharitaceae), has been introduced worldwide by aquarium trade. Hence, E. densa has been included in the database of global invasive species (GISD 2015), by the Invasive Species Specialist Group (ISSG) of the Species Survival Commission of the International Union for Conservation of 
Nature (IUCN)-World Conservation Union, although it is not in their top 100 list (Curt et al. 2010). E. densa is a perennial dioecious aquatic plant native from South America, in the neotropical range (Yarrow et al. 2009). In its introduced range, in Europe and in the United States, only male flowers have been observed, thus plants reproduce asexually by fragmentation (Cook and Urmi-König 1984). The large stands often seen in the US, Canada, New Zealand, Japan and Europe are considered to be genetic monocultures in each of these countries because of this sole reproduction strategy (Kadono et al. 1997; Darrin 2009). E. densa was introduced to France in the 1920s as experimental botanical material (St John 1961). These plants were released into the wild and have become naturalized in France, where their distribution has spread (Feuillade 1961a; 1961b). E. densa is found in both lentic and lotic environments (Yarrow et al. 2009) and it appears to be confined to warm-temperate and cool subtropical conditions. Within subtropical and tropical areas, E. densa is limited to high altitudes or coldwater springs (Cook and Urmi-König 1984). It is well adapted to cold climates and can survive freezing conditions during the winter by storing starch in its leaves and stems. It then uses these supplies for growth once temperatures rise above $10^{\circ} \mathrm{C}$. It can even live for a while under ice (Cook and Urmi-König 1984). The optimum growth temperature reported is $16^{\circ} \mathrm{C}$ and the maximum temperature for growth is $25^{\circ} \mathrm{C}$ (Cook and Urmi-König 1984). Its growth is affected by temperature (Barko and Smart 1981; Riis et al. 2012; Hussner et al. 2014) but not by $\mathrm{CO}_{2}$ availability under experimental conditions (Hussner et al. 2014). E. densa biomass has two growth maxima in August and December-January in Japan (Haramoto and Ikusima 1988) and in late summer and late autumn in South Carolina (Getsinger and Dillon 1984).

During the introduction phase, non-native aquatic species are usually introduced as stem fragments. Vegetative propagules such as stem fragments, are essential for the dispersal and colonisation of Hydrocharitaceae species (Silveira et al. 2009). The colonization of a new site by plant fragments requires regeneration (the ability of fragments to grow new shoots and 
rhizomes), and establishment (the ability of fragments to develop roots and become attached to the sediment) (Barrat-Segretain et al. 1998; Riis et al. 2009). Although abiotic variables may also influence the survival and colonisation success of plant fragments, their effects on vegetative propagules are little known. In the Upper Parana River basin, physical and chemical properties of the water seem to be related to sediment characteristics, and plant fragments reaching habitats with different physical and chemical properties may differ in their colonisation and growth success (Silveira et al. 2009). The spread of E. densa is a range expansion from established populations via dispersal by water or via unintentional introduction by humans (emptying aquariums, propagation of fragments attached to boats, etc.). The present study analysed the influence of increasing autumn temperatures on the growth, regeneration and colonisation abilities of E. densa shoots from different populations during the first stage of the introduction process. We tested four populations: three "naturalized" populations and one "cultivated" population (from an aquarium supply store). Our hypotheses were that (1) an increase of three degrees would favour growth, regeneration and colonisation of E. densa fragments and (2) naturalized populations would have higher establishment success than a cultivated population.

\section{Methods}

\section{$\underline{\text { Experimental design }}$}

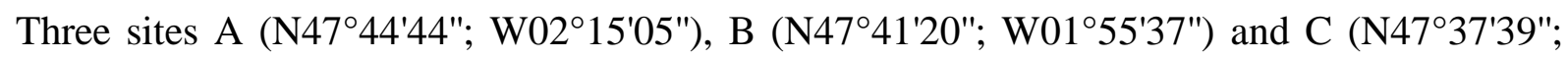
W01 $\left.51^{\prime} 35^{\prime \prime}\right)$ characterized by the presence of dense monospecific beds of E. densa were selected in Brittany, France. To characterize the environmental conditions in which E. densa was growing, we assessed the water quality of each site over the course of one year. At each sampling site, a water sample was collected in May, June, July, October and November 2013. Water temperature and the percentage of dissolved oxygen were measured in the field, whereas other parameters such as $\mathrm{pH}$, conductivity and nutrients $\left(\mathrm{PO}_{4}^{3-}, \mathrm{NH}_{4}^{+}, \mathrm{NO}_{3}{ }^{-}\right)$were analysed in 
108 the laboratory. Conductivity and $\mathrm{pH}$ were measured using a combined glass electrode and

109 corrected for temperature $\left(25^{\circ} \mathrm{C}\right)$. Reactive soluble phosphorus, nitrates and ammonia were 110 analysed using a spectrophotometer (by the standard molybdenum blue analytical technique for 111 phosphates and by the indophenol technique for ammonia, AFNOR, 1990).

112 In autumn 2013, forty shoots of E. densa were collected from each site (populations A,

113 B and C) and forty shoots of E. densa were collected from a grower in the aquarium trade 114 (population D). Shoots of population D had been grown at $26^{\circ} \mathrm{C}$ in the store.

115 Two experiments were carried out in autumn 2013. Climate change predictions for 116 northern latitudes suggest an average temperature increase of around $3^{\circ} \mathrm{C}$ over the course of 117 this century (McKee et al. 2003). To keep our experiment in line with these predictions, we 118 subjected the plants from the four populations to two experiments with a temperature increase 119 of $3^{\circ} \mathrm{C}$. Experiment 1 consisted of testing the average minimal autumn temperature $\left(9^{\circ} \mathrm{C}\right)$ and 120 a temperature $3^{\circ} \mathrm{C}$ above this value, i.e. $12^{\circ} \mathrm{C}$. In experiment 2 , we tested the average maximal 121 autumn temperature $\left(16^{\circ} \mathrm{C}\right)$, and warmer conditions of $19^{\circ} \mathrm{C}$.

122 Each experiment was set up under controlled conditions in two growth chambers 123 (Percival AR-41L3X and Percival AR-41L3X LT). Water temperatures were maintained at 124 specified levels $\left( \pm 1^{\circ} \mathrm{C}\right)$ using a temperature regulated chamber possessing both heating and 125 cooling capacities. At the beginning of the experiment, the shoots from each population of $E$. 126 densa were cleaned gently by hand to remove invertebrates, algae and debris. To each 127 transparent plastic container (with dimensions $\mathrm{L} \times \mathrm{W} \times \mathrm{H}: 8 \mathrm{~cm} \times 8 \mathrm{~cm} \times 20 \mathrm{~cm}$ ), we added 128 sediment composed of $1 \mathrm{~cm}$ of substrate (potting soil) overlaid with $1 \mathrm{~cm}$ of sand. Containers 129 were filled with $500 \mathrm{ml}$ of tap water $\left(\left[\mathrm{NH}_{4}{ }^{+}-\mathrm{N}\right]=0.030 \mathrm{mg} / \mathrm{l} ;\left[\mathrm{NO}_{3}{ }^{-}-\mathrm{N}\right]=5.77 \mathrm{mg} / \mathrm{l} ;\left[\mathrm{PO}_{4}{ }^{3+}-\mathrm{P}\right]\right.$ $130=0.010 \mathrm{mg} / \mathrm{l} ; \mathrm{pH}=8.17$; conductivity: $486 \mu \mathrm{S} / \mathrm{cm}$ ). A $10 \mathrm{~cm}$-long apical shoot (with green 131 leaves and without roots, lateral shoots or flowers) was put into each plastic container. There 132 were 10 replicates for each population and experimental temperature. The fragments grew 
133 under $330 \mu \mathrm{mol}$ photons $\mathrm{m}^{-2} \mathrm{~s}^{-1}$ as E. densa is reported to have optimum growth under these

134 light conditions (Riis et al. 2012) in a 12/12 h light/dark cycle. The containers had randomly 135 assigned positions in the growth chambers.

136 The impact of increasing temperatures on the growth of the fragments of $E$. densa was 137 examined at the four temperature levels $\left(9^{\circ} \mathrm{C}\right.$ and $12^{\circ} \mathrm{C}, 16^{\circ} \mathrm{C}$ and $\left.19^{\circ} \mathrm{C}\right)$ after 10 days of 138 exposure, when the experiments were concluded. Pistori et al. (2004) showed that the Relative

139 Growth Rate of $E$. densa was the highest between 8 to 12 days after the beginning of an 140 experiment.

141 We measured 9 morphological traits at the end of the experiment: stem length (distance

142 from shoot base to the shoot apex), internode length (mean value of ten internodes located 3-

$143 \mathrm{~cm}$ below the apex), number of buds, roots, flowers and lateral shoots. Lateral shoots included

144 any secondary lateral shoots which developed from nodes of the original apical shoot and other

145 lateral shoots that developed either from the same nodes, or from nodes of the lateral shoots (Di

146 Nino et al. 2007). We also measured the length of lateral shoots (mean value), the mean root

147 length and the area of a leaf located below the three-cm long apex. The difference between the

148 stem length at the beginning and the end of the experiment indicated the relative growth rate

149 "RGR" (Silveira et al. 2009).

$$
\mathrm{RGR}=\frac{(\ln \mathrm{L} 2-\ln \mathrm{L} 1)}{(\mathrm{t} 2-\mathrm{t} 1)}
$$

$151 \quad \mathrm{~L} 1$ and L2 refer to total length at times 1 and 2. $\underline{\text { Statistical analyses }}$ The normal distribution of the values and homogeneity of variance were checked, and a two-way ANOVA was performed to test the temperature and the population effects in experiments 1 and 2. For each significant difference ( $\mathrm{p}<0.05)$, a HSD Tukey's post-hoc test was performed to assign these differences between treatments. All data were analysed with 
Plants were collected in neutral waters with high nutrient contents, moderate conductivity and low oxygen levels (Table 1). Site A was characterized by lower conductivity and ammonium concentrations than sites B and C (Table 1).

There was a significant interaction between temperature and population for bud and flower production under the minimal temperature conditions (Figure 1, Table 2), whereas there was no flower production at maximal autumn temperatures regardless of the population source. The growth (RGR), regeneration (production of lateral branches) and colonisation abilities (length of the roots) of E. densa fragments depended both on the population and temperature at the maximal autumn temperatures (Figure 1, Table 3). An increase of $3^{\circ} \mathrm{C}$ did not affect the

168 production of buds, internode length or leaf area in any of the experiments. However, an 169 increase of $3{ }^{\circ} \mathrm{C}$ did have a significant effect on the apical growth (RGR) of $E$. densa at the minimal temperatures (experiment $1,9-12^{\circ} \mathrm{C}$ ), and on the regeneration abilities (production of

171 lateral branches) at the maximal autumn temperatures (Figure 2; Tables 2, 3). The temperature 172 increase from $16^{\circ} \mathrm{C}$ to $19^{\circ} \mathrm{C}$ also favoured the colonisation abilities (production of $E$. densa 173 roots and their growth), whereas no roots or lateral branches were produced at $9{ }^{\circ} \mathrm{C}$ and $12^{\circ} \mathrm{C}$ 174 (Figure 2).

A significant population effect was established for all of the traits that were measured 176 in both experiments, except for the RGR at minimal temperatures. Fragments from population 177 A were characterized by lower growth (RGR and internode length), reduced leaf area and lower 178 root development (number and length) than those of population $\mathrm{C}$, and lower lateral shoots than 179 those of the cultivated population (D) at maximal autumn temperatures (Figure 3). Fragments 180 from population B had the highest leaf area in both experiments and developed high apical 181 growth rates (RGR, internode length) and root production at maximal autumn temperatures 182 (Figure 3). Fragments from population C allocated their energy to growth (the highest RGR) at 
183 the maximal autumn temperatures (Figure 3). The fragments from the cultivated population D

184 had lower growth (lowest RGR at $16^{\circ} \mathrm{C}$ ) and higher regeneration abilities (number of lateral 185 shoots) than the naturalized populations at maximal autumn temperatures (Figure 3). This 186 population was characterized by low leaf area (the lowest at minimal temperatures and among 187 the lowest at maximal autumn temperatures). Population D was the only one which produced 188 flowers at minimal temperatures (Figure 3).

\section{Discussion}

Our preliminary results showed that temperature and the origin of the population both

191 had an effect on the growth of E. densa (RGR), its regeneration (production of lateral branches)

192 and its colonisation (the length of the roots) abilities at the maximal autumn temperatures and 193 also on the production of buds and flowers at minimal autumn temperatures. An increase of $19433^{\circ} \mathrm{C}$ at low temperatures slightly favoured the apical growth (RGR) of E. densa, whereas an 195 increase in temperature from $16^{\circ} \mathrm{C}$ to $19^{\circ} \mathrm{C}$ stimulated the regeneration and colonisation 196 abilities (number and length of roots). Our first hypothesis is supported.

197 We also demonstrated that the potential success of $E$. densa fragments to establish was 198 strongly influenced by the origin of the population. Fragments of E. densa from naturalized 199 populations elongated much faster than those from the cultivated population. Although the three naturalized populations were acclimatized in Brittany, they showed different responses to

201 increasing temperature: fragments from population A had low growth, regeneration and 202 colonisation abilities, whereas the fragments from populations B and C had high regeneration 203 abilities and growth rates. Our results must be interpreted conservatively because differences 204 between the traits of fragments from populations A, B and C could be due to "ecotypes" or 205 "clonal adaptation". The cultivated population had lower growth than the naturalized 206 populations when submitted to autumn temperatures: fragments allocated their energy 
essentially to the production of lateral shoots (regeneration). Our second hypothesis is also supported.

We found very low growth of $E$. densa at $9^{\circ} \mathrm{C}$, but significantly higher growth when the temperature increased to $12^{\circ} \mathrm{C}$. The increase in temperature from $16^{\circ} \mathrm{C}$ to $19^{\circ} \mathrm{C}$ stimulated the 211 production of lateral branches amongst population D and the apical growth of fragments from 212 all populations. These results are congruent with data in the literature (Getsinger and Dillon 213 1984; Haramoto and Ikusima 1988; Hussner et al. 2014). Haramoto and Ikusima (1988) showed 214 that below $10^{\circ} \mathrm{C}$, the growth of E. densa stops. Similarly, the autumn biomass peak was recorded when the water temperature had reached approximately $10^{\circ} \mathrm{C}$ in Lake Marion in South Carolina (Getsinger and Dillon 1984). Haramoto and Ikusima (1988) also showed that lateral shoots with roots were developed and elongated towards the water surface when the water temperature rose above $15^{\circ} \mathrm{C}$, and that optimum growth rate occurred at a temperature of $20.7^{\circ} \mathrm{C}$. We measured the highest RGR $\left(0.032 \mathrm{day}^{-1}\right)$ for population $\mathrm{C}$ at $19^{\circ} \mathrm{C}$ and the lowest for population $\mathrm{A}$ at $19^{\circ} \mathrm{C}\left(\mathrm{RGR}=0.018 \mathrm{day}^{-1}\right)$. According to laboratory findings from other studies, the average measured RGR of fragments from naturalized populations of E. densa is consistent with the data reported in the literature for that temperature range (Barko and Smart 1981; Haramoto and Ikusima 1988; Tanner et al. 1993; Carrillo et al. 2006; Silveira et al. 2009; Hussner et al. 2014).

In this study, we showed that the high capacity of $E$. densa populations to adjust their growth responses depends on both the environmental temperature conditions and the origin of the plants. The acclimation potential towards cold temperatures may be closely related to the temperatures experienced in the area where plants were collected. Indeed, the responses of the three naturalized populations of E. densa when acclimated to $9{ }^{\circ} \mathrm{C}$ and $12^{\circ} \mathrm{C}$ were similar, and differed significantly from the cultivated population for the number of flowers, internode length and leaf area. All naturalized populations may have partly entered into a dormant stage due to 
232 the minimal temperatures, as seen in other studies (Madsen and Brix 1997; Hyldgaard et al. 233 2014). This possibility is supported by observed morphological changes, such as shoots of the 234 naturalized plants tested at $9^{\circ} \mathrm{C}$ and $12 \mathrm{C}$, which were less compact in structure and had longer 235 distances between whorls (mean internode length $=0.36 \pm 0.07 \mathrm{~cm}$ ) than the plants exposed to $23616^{\circ} \mathrm{C}$ and $19^{\circ} \mathrm{C}$ (mean internode length $=0.50 \pm 0.17 \mathrm{~cm}$ ). In contrast, the fragments from the 237 cultivated population produced flowers and buds when they were exposed to the low 238 temperatures.

The three naturalized populations were collected from neighbouring sites in Brittany 240 and therefore they had been exposed to the same climatic conditions prior to the experiments. 241 The environmental conditions in the field could explain some differences in the responses 242 between the three naturalized populations of $E$. densa tested. Feijoó et al. (2002) found that $E$. 243 densa shows a clear preference for ammonium over nitrate and that most nitrogen was absorbed 244 from the water column. Moreover E. densa can store nutrients in their leaves and stems. The comparatively high concentration of ammonium in sites B and C could suggest that nitrogen was stored in the plants and used later for growth (luxury consumption hypothesis). This could 247 explain the higher growth rate of E. densa from the sites B and C. Furthermore, the RGR is 248 directly controlled by the concentration of $\mathrm{N}$ within the plant (Ågren 1985) and high concentrations of $\mathrm{N}$ in the tissues may favour plant growth.

In Western Europe, as only male plants and clonal reproduction have been observed, the wide range of morphological variations within E. densa species suggest that either a large 252 number of diverse clonal lineages were introduced, or that this plant has high levels of somatic 253 mutation. For functional traits such as growth rate, phenotypic plasticity can allow invasive 254 plants to benefit from changing environmental conditions (Richards et al. 2006). Morphological plasticity may evolve rapidly in introduced species, and thereby contribute to their spread and invasion success after a time-lag (e.g. Sexton et al. 2002). Results of the present study 
confirmed that $E$. densa could act aggressively as an invasive plant by showing plasticity for ecological traits that are beneficial to its range expansion. At this time, we do not have information about potential genetic differences between the different populations of $E$. densa. Our hypothesis should be tested by genetic approaches.

Our preliminary results suggest that $E$. densa may be able to develop taller canopies in the future, in particular in autumn, which might improve their survival during the winter and accelerate their growth in early spring. To test our hypothesis, it would be necessary to assess the responses of these different populations of E. densa during a long term study. We emphasize that our observations were recorded in the early stages of fragment regeneration, and whether they also pertain to later life stages is a matter for further investigation. Moreover, E. densa has the ability to adapt to seasonal changes in temperature in its natural habitat (Haramoto and Ikusima 1988). The growth rate of E. densa in autumn will be sensitive to the increase of temperatures expected in the context of global warming. These results should be tested in the

field. The present study has investigated the growth responses of $E$. densa to varying

272 in the field (e.g. light, macrophyte beds, disturbance, nutrients, water velocity, etc). Research 273 on the response of this species to increasing temperatures in parallel to other environmental 274 factors is required to improve our understanding of the impact of global warming on the 275 invasiveness of aquatic plants.

\section{References:}

AFNOR (1990). Recueil des normes françaises. Eaux. Méthodes d'essais. 4ème ed, Paris, 736 p.

279 Ågren GI (1985) Theory for growth of plants derived from the nitrogen productivity concept. Physiol Plant 64:17-28. doi: 10.1111/j.1399-3054.1985.tb01207.x

Barko JW, Smart RM (1981) Comparative influences of light and temperature on the growth and metabolism of selected submersed freswater macrophytes. Ecol Monogr 51:219235. 
Barrat-Segretain MH, Bornette G, Hering-Vilas-Bôas A (1998) Comparative abilities of vegetative regeneration among aquatic plants growing in disturbed habitats. Aquat Bot 60:201-211. doi: 10.1016/S0304-3770(97)00091-0

Bradley NL, Leopold AC, Ross J, Huffaker W (1999) Phenological changes reflect climate change in Wisconsin. Proc Natl Acad Sci U S A 96:9701-9704. doi: 10.1073/pnas.96.17.9701

Carrillo Y, Guarín A, Guillot G (2006) Biomass distribution, growth and decay of Egeria densa in a tropical high-mountain reservoir (NEUSA, Colombia). Aquat Bot 85:7-15. doi: 10.1016/j.aquabot.2006.01.006

Cook CKD., Urmi-König K (1984) A revision of the genus Egeria (Hydrocharitaceaea). Aquat Bot 19:73-96.

Curt MD, Curt G, Aguado PL, Fernández J (2010) Proposal for the Biological Control of Egeria densa in Small Reservoirs : A Spanish Case. J Aquat Plant Manag 48:124-127.

Darrin H (2009) Invasive Species of the Pacific Northwest : Brazilian Elodea, Egeria densa, Anacharis, Philotria densa, Giant Elodea, Brazilian waterweed.

Di Nino F, Thiébaut G, Muller S (2007) Phenology and phenotypic variation of genetically uniform populations of Elodea nuttallii (Planch.) H. St John at sites of different trophic states. Fundam Appl Limnol 168:335-343. doi: 10.1127/1863-9135/2007/0168-0335

Feijoó C, García ME, Momo F, Toja J (2002) Nutrient Absorption by the Submerged Macrophyte. Limnetica 21:93-104.

Feuillade J (1961a) Une plante aquatique nouvelle pour la France Elodea densa (Planch.) Casp. Bull la Soc Lineenne Normandie 10:47-51.

Feuillade J (1961b) Note complémentaire sur Elodea densa (Planch.) Casp. Bull la Soc Lineenne Normandie 10:185-188.

Fitter AH, Fitter RSR, Harris ITB, Williamson MH (1995) Relationships between 1st flowering date and temperature in the flora o a locality in central England. Funct Ecol 9:55-60.

Gallinat AS, Primack RB, Wagner DL (2015) Autumn, the neglected season in climate change research. Trends Ecol Evol 30:1-8. doi: 10.1016/j.tree.2015.01.004

Getsinger KD, Dillon CR (1984) Quiescence, growth and senescence of Egeria densa in Lake Marion. Aquat Bot 20:329-338. doi: 10.1016/0304-3770(84)90096-2

GISD (Global Invasive Species Database) (2015) Egeria densa. http://www.issg.org/database/species/search.asp?sts=sss\&st=sss\&fr=1\&x=23\&y=1\&sn= Egeria+densa\&rn=\&hci=-1\&ei=-1\&lang=EN. Accessed 11 May 2015 Naturalized in Japan. Aquat Bot 30:389-403. 
Hellmann JJ, Byers JE, Bierwagen BG, Dukes JS (2008) Five potential consequences of climate change for invasive species. Conserv Biol 22:534-43. doi: 10.1111/j.15231739.2008.00951.x

Hussner A, van Dam H, Vermaat JE, Hilt S (2014) Comparison of native and neophytic aquatic macrophyte developments in a geothermally warmed river and thermally normal channels. Fundam Appl Limnol / Arch für Hydrobiol 185:155-165. doi: 10.1127/fal/2014/0629

Hyldgaard B, Sorrell B, Brix H (2014) Closely related freshwater macrophyte species, Ceratophyllum demersum and C. submersum, differ in temperature response. Freshw Biol 59:777-788. doi: 10.1111/fwb.12303

IPANE (2015) Invasive Plant Atlas of New England - Egeria densa. https://www.eddmaps.org/ipane/ipanespecies/aquatics/Egeria_densa.htm. Accessed 12 Oct 2015

Kadono Y, Nakamura T, Suzuki T (1997) Kadono 1997 Genetic uniformity of two aquatic plants, Egeria densa Planch. And Elodea nuttallii (Planch.) St. John, introduced in Japan.pdf. Japan J Limnol 58:197-203.

Madsen T V., Brix H (1997) Growth, photosynthesis and acclimation by two submerged macrophytes in relation to temperature. Oecologia 110:320-327. doi: $10.1007 / \mathrm{s} 004420050165$

Mainka SA, Howard GW (2010) Climate change and invasive species: double jeopardy. Integr Zool 5:102-111. doi: 10.1111/j.1749-4877.2010.00193.x

McKee D, Atkinson D, Collings SE, et al (2003) Response of freshwater microcosm communities to nutrients, fish, and elevated temperature during winter and summer. Limnol Oceanogr 48:707-722. doi: 10.4319/1o.2003.48.2.0707

Pistori RET, Camargo AFMC, Henry-Silva G. (2004) Relative growth rate and doubling time of the submerged aquatic macrophyte Acta Limnol. Bras. 16:77-84.

Richards CL, Bossdorf O, Muth NZ, et al (2006) Jack of all trades, master of some? On the role of phenotypic plasticity in plant invasions. Ecol Lett 9:981-993. doi: 10.1111/j.1461-0248.2006.00950.x

Riis T, Olesen B, Clayton JS, Lambertini C, Brix H, Sorrel B (2012) Growth and morphology in relation to temperature and light availability during the establishment of three invasive aquatic plant species. Aquat Bot 102: 56-60.

Sexton JP, Mckay JK, Sala A (2002) Plasticity and Genetic Diversity May Allow Saltcedar to Invade Cold Climates in North America. 12:1652-1660.

Silveira MJ, Thomaz SM, Mormul RP, Camacho FP (2009) Effects of desiccation and sediment type on early regeneration of plant fragments of three species of aquatic macrophytes. Int Rev Hydrobiol 94:169-178. doi: 10.1002/iroh.200811086 
357 St John H (1961) Monograph of the genus Egeria Planchon. Darwiniana 12:299-310.

358 Tanner CC, Clayton JS, Wells RDS (1993) Effects of suspended solids on the establishment and growth of Egeria densa. Aquat Bot 45:299-310. doi: 10.1016/0304-3770(93)90030$\mathrm{Z}$

Yarrow M, Marin V., Finlayson M, et al (2009) The ecology of Egeria densa Planchon ( Liliopsida : Alismatales ): A wetland ecosystem engineer ? Rev Chil Hist Nat 82:299_ 313.

364 Acknowledgements

365 We thank Etienne Camenen for his helpful assistance. We would like to thank the two 366 anonymous reviewers for comments on the manuscript. 


\begin{tabular}{|c|c|c|c|c|c|c|c|c|c|c|c|c|c|c|c|c|c|c|c|c|c|}
\hline \multirow[t]{2}{*}{ sites } & \multirow{2}{*}{\multicolumn{3}{|c|}{$\begin{array}{c}\text { Temperature } \\
{ }^{\circ} \mathrm{C}\end{array}$}} & \multicolumn{3}{|c|}{$\mathrm{H}$} & \multirow{2}{*}{\multicolumn{3}{|c|}{$\begin{array}{c}\text { Conductivity } \\
\mu S . \mathrm{cm}^{-1}\end{array}$}} & \multirow{2}{*}{\multicolumn{3}{|c|}{$\begin{array}{l}\mathrm{N}-\mathrm{NO}_{3-}^{-} \\
\mathrm{mg} \cdot \mathrm{L}^{-1}\end{array}$}} & \multirow{2}{*}{\multicolumn{3}{|c|}{$\begin{array}{l}\mathrm{P}-\mathrm{PO}_{4}{ }^{3-} \\
\mu \mathrm{g} \cdot \mathrm{L}^{-1}\end{array}$}} & \multirow{2}{*}{\multicolumn{3}{|c|}{$\frac{\mathrm{N}-\mathrm{NH}_{4}+}{\mu \mathrm{g} \cdot \mathrm{L}^{-1}}$}} & \multirow{2}{*}{\multicolumn{3}{|c|}{$\begin{array}{l}\mathrm{O}_{2} \\
\%\end{array}$}} \\
\hline & & & & & & & & & & & & & & & & & & & & & \\
\hline$A$ & 6.9 & \pm & 2 & 35 & $\underline{1}$ & 1. & 27.5 & \pm & 15.2 & 4.41 & \pm & 0.7 & 105 & \pm & 0.1 & 75 & \pm & & 29 & \pm & 20 \\
\hline B & 16.3 & \pm & 5.9 & 7.415 & \pm & 0.9 & 415.7 & \pm & 60 & 3.53 & \pm & 3.2 & 0.356 & \pm & 0.4 & 0.992 & \pm & 0.5 & 34 & \pm & 1.7 \\
\hline C & 15.6 & \pm & 4.5 & 7.958 & \pm & 1,0 & 345.7 & \pm & 13.3 & 3.92 & \pm & 3.5 & 0.118 & \pm & 0.1 & 0.977 & & 0.5 & 27 & \pm & 4.9 \\
\hline
\end{tabular}

370 Table 1: Water chemical composition of the three sampling sites (annual mean value, $n=4$ ). 371 


\begin{tabular}{|c|c|c|c|}
\hline & $\begin{array}{l}\text { Degree of } \\
\text { freedom }\end{array}$ & $\mathrm{F}$ & $\mathrm{p}$ \\
\hline \multicolumn{4}{|l|}{ Relative Growth Rate } \\
\hline population & 3 & 1.51 & 0.22 \\
\hline temperature & 1 & 4.60 & 0.04 \\
\hline population $\mathrm{x}$ temperature & 3 & 1.83 & 0.15 \\
\hline \multicolumn{4}{|l|}{ Number of buds } \\
\hline population & 3 & 6.28 & 0.0068 \\
\hline temperature & 1 & 0.56 & 0.14 \\
\hline population $\mathrm{x}$ temperature & 3 & 3.09 & 0.025 \\
\hline \multicolumn{4}{|l|}{ Internode length } \\
\hline population & 3 & 46.87 & $<0.0001$ \\
\hline temperature & 1 & 0.13 & 0.72 \\
\hline population $\mathrm{x}$ temperature & 3 & 0.56 & 0.65 \\
\hline \multicolumn{4}{|l|}{ Leaf area } \\
\hline population & 3 & 30.20 & $<0.0001$ \\
\hline temperature & 1 & 0.13 & 0.72 \\
\hline population $\mathrm{x}$ temperature & 3 & 0.30 & 0.83 \\
\hline \multicolumn{4}{|l|}{ Number of flowers } \\
\hline population & 3 & 6.95 & 0.0004 \\
\hline temperature & 1 & 6.70 & 0.01 \\
\hline population $\mathrm{x}$ temperature & 3 & 6.95 & 0.0004 \\
\hline
\end{tabular}

373 Table 2: F-Values and significance of two-way ANOVA of the effects of population and 374 temperature on growth and morphology parameters of Egeria densa submitted to minimal 375 autumn temperature (Experiment $1,9-12^{\circ} \mathrm{C}$ ). 


\begin{tabular}{|c|c|c|c|}
\hline Relative Growth Rate & $\begin{array}{l}\text { Degree of } \\
\text { freedom }\end{array}$ & $\mathrm{F}$ & $p$ \\
\hline population & 3 & 17.30 & $<0.0001$ \\
\hline temperature & 1 & 2.55 & 0.11 \\
\hline population $\mathrm{x}$ temperature & 3 & 3.66 & 0.016 \\
\hline \multicolumn{4}{|l|}{ Internode length } \\
\hline population & 3 & 5.11 & 0.003 \\
\hline temperature & 1 & 0.17 & 0.68 \\
\hline population $\mathrm{x}$ temperature & 3 & 1.22 & 0.31 \\
\hline \multicolumn{4}{|l|}{ Number of Buds } \\
\hline population & 3 & 6.28 & 0.0008 \\
\hline temperature & 1 & 0.56 & 0.46 \\
\hline population $\mathrm{x}$ temperature & 3 & 3.09 & 0.03 \\
\hline \multicolumn{4}{|c|}{ Number of lateral branches } \\
\hline population & 3 & 18.56 & $<0.0001$ \\
\hline temperature & 1 & 4.64 & 0.03 \\
\hline population $\mathrm{x}$ temperature & 3 & 3.15 & 0.03 \\
\hline \multicolumn{4}{|l|}{ Length of Lateral Shoots } \\
\hline population & 3 & 6.45 & 0.0006 \\
\hline temperature & 1 & 1.73 & 0.19 \\
\hline population $\mathrm{x}$ temperature & 3 & 1.92 & 0.13 \\
\hline \multicolumn{4}{|l|}{ Number of Roots } \\
\hline population & 3 & 4.78 & 0.004 \\
\hline temperature & 1 & 10.19 & 0.002 \\
\hline population $\mathrm{x}$ temperature & 3 & 2.02 & 0.12 \\
\hline \multicolumn{4}{|l|}{ Length of roots } \\
\hline population & 3 & 7.30 & 0.0002 \\
\hline temperature & 1 & 7.26 & 0.009 \\
\hline population $\mathrm{x}$ temperature & 3 & 3.93 & 0.01 \\
\hline \multicolumn{4}{|l|}{ Leaf area } \\
\hline population & 3 & 10.29 & $<0.0001$ \\
\hline temperature & 1 & 0.06 & 0.80 \\
\hline population $\mathrm{x}$ temperature & 3 & 0.85 & 0.47 \\
\hline
\end{tabular}

379 Table 3: F-Values and significance of two-way ANOVA of the effects of population and 380 temperature on growth and morphology parameters of Egeria densa submitted to maximal 381 autumn temperature (Experiment 2, $16-19^{\circ} \mathrm{C}$ ). 
Figure captions

384 Figure 1: Comparison of the effect of population and temperature on bud number at $9-12^{\circ} \mathrm{C}$ 385 (experiment 1) and on Relative Growth Rate (RGR) at $16-19^{\circ} \mathrm{C}$ (experiment 2) between $E$. 386 densa populations. Different letters indicate significant differences for $E$. densa with temperature and population (ANOVA, $\mathrm{p}<0.05$ ). Bars indicate standard deviation.

Figure 2: Comparison of the significant effects of temperature on traits between $E$. densa populations in experiments 1 and 2. Different letters indicate significant differences for $E$. densa with temperature (ANOVA, $\mathrm{p}<0.05)$. Bars indicate standard deviation.

Figure 3: Comparison of the significant effects of population on traits between $E$. densa populations in experiments 1 and 2. Different letters indicate significant differences for $E$. densa with population according to ANOVA, $\mathrm{p}<0.05$ and Tukey test. Bars indicate standard 396 deviation. 